\title{
Numerical investigation of the effect of flow circulation pattern and velocity on the performance of water-cooled heat sink
}

\author{
Akıs yönü ve hızının su soğutmalı ısı alıcısı performansına etkisinin nümerik incelenmesi
}

\author{
Seyda ÖZBEKTAŞ ${ }^{1, a}$, Bilal SUNGUR ${ }^{* 2, b}$, Bahattin TOPALOĞLU ${ }^{1, c}$ \\ ${ }^{1}$ Ondokuz Mayls Üniversitesi, Mühendislik Fakültesi, Makine Mühendisliği Bölümü, 55139, Samsun \\ ${ }^{2}$ Samsun Üniversitesi, Mühendislik Fakültesi, Makine Mühendisliği Bölümü, 55420, Samsun
}

• Geliş tarihi / Received: 06.04.2021 • • Düzeltilerek geliş tarihi / Received in revised form: 22.10.2021 • Kabul tarihi / Accepted: 01.11 .2021

\begin{abstract}
The most critical problems of electronic components are the high power consumption and lesser life. This paper aims to numerically model the working process of the water-cooled heat sink to obtain the most effective design. In this context, four types of configurations with different passes (Type-A, Type-B, Type-C, Type-D) were designed at different water velocities, which were $0.25 \mathrm{~m} / \mathrm{s}, 0.5 \mathrm{~m} / \mathrm{s}$, and $1 \mathrm{~m} / \mathrm{s}$ with constant air velocity $(6 \mathrm{~m} / \mathrm{s})$ to simulate fluid flow and the heat transfer. Results were evaluated as temperature and pressure contours, velocity streamlines, and the graphics of pressure difference, outlet temperature, temperature difference, heat transfer rate to air, and power consumption in relation to Reynolds number. Results showed that pressure difference, outlet temperature, power consumption, and heat transfer rate to air increased by increasing Reynolds number in all analyses. In all configurations, the water outlet temperatures were very close to each other, in the range of $63-65{ }^{\circ} \mathrm{C}$ for $\mathrm{Re}=2500,70-72{ }^{\circ} \mathrm{C}$ for $\mathrm{Re}=5000$, and $74-76{ }^{\circ} \mathrm{C}$ for $\mathrm{Re}=10000$. Among all configurations, Type-A has the minimum outlet temperature with the value of $63.40{ }^{\circ} \mathrm{C}$ for $\mathrm{Re}=2500,70.77$ ${ }^{\circ} \mathrm{C}$ for $\mathrm{Re}=5000$, and $74.85{ }^{\circ} \mathrm{C}$ for $\mathrm{Re}=10000$. Also, Type-A showed better performance than other models in terms of heat transfer rate to air with the value of $1346 \mathrm{~W}$ for $\mathrm{Re}=2500,1500 \mathrm{~W}$ for $\mathrm{Re}=5000$, and $1675 \mathrm{~W}$ for $\mathrm{Re}=10000$. The maximum pressure difference was obtained in Type-A geometry with the value of nearly $3500 \mathrm{~Pa}$ at a Reynolds number value of 10000 . When the results were evaluated in full scope, it was concluded that Type-B was the most suitable model for use in terms of heat transfer, pump power, and inlet-outlet positions.
\end{abstract}

Keywords: Electronic cooling, Heat sink, Liquid cooling, Numerical modeling

$\ddot{O} z$

Elektronik bileşenlerin en önemli sorunlarl, yüksek güç tüketimi ve kısa ömürdür. Bu çalışmanın amacı, su soğutmalı ısı alıcının çalışma sürecini sayısal olarak modellemek ve bu sayede en etkili tasarımı elde etmektir. Bu kapsamda akış ve ısı transferini simüle etmek için suyun $0.25 \mathrm{~m} / \mathrm{s}, 0.5 \mathrm{~m} / \mathrm{s}$ ve $1 \mathrm{~m} / \mathrm{s}$ hılarında ve sabit hava hızında $(6 \mathrm{~m} / \mathrm{s})$ farklı geçişlere sahip dört farkl geometri (Tip-A, Tip-B, Tip-C, Tip-D) dizayn edilmiştir. Sonuçlar, sıcaklık ve basınç konturlarl, akım çizgileri ve basınç farkı, çıkışs sıcaklığı, sıcaklık farkı, havaya olan ısı transferi ve güç tüketiminin Reynolds ile değişimi grafiklerine bağlı olarak değerlendirilmiştir. Tüm analizlerde Reynolds sayısının artışıyla birlikte basınç farkı, çıkış sıcaklı̆̆l, güç tüketimi ve havaya olan ısı transferi artmıştır. Tüm modellerde suyun çıkış sıcaklıkları birbirine çok yakın olup $R e=2500$ için $63-65^{\circ} \mathrm{C}, R e=5000$ için $70-72{ }^{\circ} \mathrm{C}$ ve $R e=10000$ için $74-76{ }^{\circ} \mathrm{C}$ aralığındadır. Tüm modeller arasında $R e=2500$ için $63.40^{\circ} \mathrm{C}, R e=5000$ için $70.77^{\circ} \mathrm{C}$ ve Re=10000 için $74.85^{\circ} \mathrm{C}$ değerleriyle en düşük çıkıs sıcaklığına Tip- $\mathrm{A}$ sahiptir. Ayrıca Tip-A, Re=2500 için $1346 \mathrm{~W}, \mathrm{Re}=5000$ için $1500 \mathrm{~W}$ ve Re=10000 için $1675 \mathrm{~W}$ değerleri ile havaya olan ısı transferi açısından diğer modellere göre daha iyi performans göstermiştir. En yüksek basınç farkl, 10000 Reynolds sayısında yaklaşık olarak $3500 \mathrm{~Pa}$ değeriyle Tip-A geometrisinde elde edilmiştir. Sonuçlar bütünüyle değerlendirildiğinde, Tip-B'nin ısı transferi, pompa gücü ve giriş-çıkış pozisyonları açısından kullanıma en uygun model olduğu sonucuna varılmıştır.

Anahtar kelimeler: Elektronik soğutma, Isı alıcı, Sıvı soğutma, Nümerik modelleme

\footnotetext{
${ }^{* b}$ Bilal SUNGUR; bilal.sungur@samsun.edu.tr, Tel: (0362) 31300 55, orcid.org/0000-0002-7320-1490

${ }^{\mathrm{a}}$ orcid.org/0000-0001-7399-733X $\quad{ }^{\mathrm{c}}$ orcid.org/0000-0002-7095-4913
} 


\section{Introduction \\ 1. Giriş}

Technological developments in recent years have led to a great decrease in the size of electronic devices, which means higher heat flux generation. Heat transfer in these devices has become critical in the manufacturing and engineering problems to control the working temperature within acceptable limits by devising more effective ways to remove the waste heat. Therefore, the need for more compact, reliable, and modern cooling technologies is increasing. There have been numerous methods for effective cooling, such as heat pipe and jet impingement (Nishino et al., 1996; Zhao and Avedisian, 1997; Chung and Luo, 2002; Kim et al., 2003). Generally, heat sinks with air at high pressure are used for electronic cooling because of their low cost, weight and reliability. The main parameters for designing an efficient heat sink are simpler structure, higher heat transfer rate, and lower pressure drop. The micro-channeled heat sink cooling concept is one of the candidates which is offered in 1981 by Tuckerman and Pease (Tuckerman and Pease, 1981). The advantage of this cooling concept is that the large surface area of heat transfer and thus a higher heat transfer (Knight et al., 1992; Wang and Peng, 1994; Adams et al., 1998; Hetsroni et al., 2005; Pastukhov and Maydanik, 2006). The heat transfer coefficient of water is nearly one hundred times higher than that of air (Réti, 1999). Thus, using water as a working fluid called a liquid cooling system is evaluated as a potential system that can provide heat removal. The main parts of a liquid cooling system are the pump, water-block, radiator, fan and reservoir. The working fluid, driven by a pump, circulates through pipes located inside the electronic device. In a $\mathrm{CPU}$, heat generation occurs and to cool the CPU, the working fluid passes through a water-block equipped in a CPU. After this, the working fluid becomes warmer, and it enters the radiator to be cooled by external air. Then, the cooled working fluid circulates back to the heating area, repeating continuously. The cooled working fluid circulates back to the heating region, and the same process is repeated and the cycle continues.

Some researchers have improved such techniques by inserting fins to dissipate heat effectively (Nishino et al., 1996; Zhao and Avedisian, 1997; Wang and Vafai, 2000). Jajja et al. (Jajja et al., 2014) investigated the thermal management of higher heat generation in microprocessors with five different heat sinks with different fin spacings. Their results showed that thermal resistance and the base temperature of the heat sinks are decreased by reducing the fin spacing and by increasing the volume flow rate of coolant through the heat sink. In the study of Wei and Joshi (Wei and Joshi, 2003), they obtained that optimizing the channel configuration such as aspect ratio, fin thickness and a ratio of channel width to fin thickness provided a reduction in thermal resistance. Toh et al. (Toh et al., 2002) numerically investigated the cooling behavior of an electronic device in laminar flow conditions. They observed that increasing the temperature decreased the viscosity and friction losses at the same Reynolds number. The role of conduction heat transfer in a heat sink was investigated by Tiselj et al. (Tiselj et al., 2004). They stated a nonlinear relationship in the heat transfer between the cooler and the surface wall.

Naphon et al. (Naphon et al., 2009) numerically investigated the fluid flow and heat transfer in the mini-rectangular fin heat sink for CPU. They stated that there is a reasonable agreement between the predicted results and experiments. Naphon et al. (Naphon and Wiriyasart, 2009) experimentally investigated the liquid cooling in the minirectangular fin heat sink with and without thermoelectric for CPU. They compared thermoelectric cooling with the other cooling techniques and found that the thermoelectric has a significant effect on the CPU cooling of PC. Cova et al. (Cova et al., 2013) investigated the cooling effect of power converters with water as coolant in the heat sink. Xie et al. (Xie et al., 2006) numerically investigated the pressure drop and turbulent heat transfer characteristics in a watercooled mini channel heat sink. Conrad et al. (Conrad et al., 2015) studied the thermal behavior of a heat sink with pin-fin on the chip. They stated that suspending the nano-sized particles in the range of $1-100 \mathrm{~nm}$ in the base fluids enhanced the thermal conductivity of a fluid.

With the developments in computer and CFD technology, the flow and heat transfer process simulation becomes more reliable and faster. The manufacturers which produce liquid coolers for CPUs in the market claim that they get better performance in terms of heat transfer by making changes in the circulation pattern of the liquid inside the channels of the liquid cooler. This work provides an idea about the accuracy of these claims. Thus, the main aim of this paper is numerically investigate the working process of the water-cooled heat sink, which is often used in electronic devices. In literature, studies generally focused on the geometrical effects of the water channels and the fluids used in the channels on fluid flow and heat transfer characteristics. There is 
a lack on the effects of the passes and the paths on heat transfer and fluid flow characteristics in a water-cooled heat sink. Also, studies in which the analysis of the heat transfers both in the water and air sides are considered are very limited. In this study, four types of water block with different passes were designed to simulate fluid flow and heat transfer at three different water velocities. To model the turbulent flow, Standart k- $\varepsilon$ model was used. Results were evaluated as temperature and pressure contours, velocity streamlines and the graphics of pressure difference, outlet temperature, temperature difference, total thermal resistance, heat transfer rate to air, hydraulic power in relation to Reynolds number.

\section{Materials and methods}

\section{Materyal ve metod}

Turbulent flows can be modeled using the finite volume method with Computational Fluid Dynamics (CFD) programs. In the calculation of flow problems, mass, momentum, and energy conservation equations need to be solved. These differential equations are solved using boundary conditions suitable for problems. For turbulent steady-state flow, time-averaged continuity, momentum, and energy equations were expressed as follows:

$\frac{\partial \mathrm{U}_{\mathrm{i}}}{\partial \mathrm{x}_{\mathrm{i}}}=0$

$\mathrm{U}_{\mathrm{j}} \frac{\partial \mathrm{U}_{\mathrm{i}}}{\partial \mathrm{x}_{\mathrm{j}}}=\frac{\partial}{\partial \mathrm{x}_{\mathrm{j}}}\left(v \frac{\partial \mathrm{U}_{\mathrm{i}}}{\partial \mathrm{x}_{\mathrm{j}}}-\overline{\mathrm{u}_{\mathrm{i}} \mathrm{u}_{\mathrm{j}}}\right)-\frac{1}{\rho} \frac{\partial \mathrm{P}}{\partial \mathrm{x}_{\mathrm{i}}}$
$\mathrm{U}_{\mathrm{j}} \frac{\partial \mathrm{T}}{\partial \mathrm{x}_{\mathrm{j}}}=\frac{\partial}{\partial \mathrm{x}_{\mathrm{j}}}\left(\alpha \frac{\partial \mathrm{U}_{\mathrm{i}}}{\partial \mathrm{x}_{\mathrm{j}}}-\overline{\mathrm{u}_{\mathrm{j}} \mathrm{t}}\right)$

where $U_{i}$, is the mean-velocity vector, $P$ is the mean static pressure, $\rho$ is the fluid density and $v$ is the fluids kinematic viscosity. Reynolds stresses $\left(\overline{\mathrm{u}_{1} \mathrm{u}_{\mathrm{j}}}\right)$ in momentum conservation equation is defined by

$-\overline{\mathrm{u}_{\mathrm{i}} \mathrm{u}_{\mathrm{j}}}=v_{\mathrm{t}}\left(\frac{\partial \mathrm{U}_{\mathrm{i}}}{\partial \mathrm{x}_{\mathrm{j}}}+\frac{\partial \mathrm{U}_{\mathrm{j}}}{\partial \mathrm{x}_{\mathrm{i}}}\right)-\frac{2}{3} \delta_{\mathrm{ij}} \mathrm{k}$

where $v_{\mathrm{t}}$ is turbulent viscosity and defined as:

$v_{\mathrm{t}}=\mathrm{C}_{\mu} \frac{\mathrm{k}^{2}}{\varepsilon}$

where $\mathrm{k}$ is the turbulent kinetic energy and $\varepsilon$ is turbulent dissipation rate.

There are lots of turbulence models to simulate the turbulent flow and Standart k- $\varepsilon$ model is one of them which is widely used for the heat transfer and fluid flow analysis (Choi et al., 2011). Due to this reason, Standart k- $\varepsilon$ turbulence model was used in this study. The Standard k- $\varepsilon$ model is a semiempirical two-equation model based on modeling the transport equations for turbulent kinetic energy (k) and turbulent dissipation rate $(\varepsilon)$. In this model, turbulent viscosity is assumed to be proportional to turbulent velocity and length scale. These velocity and length scales are derived from the turbulent kinetic energy $(\mathrm{k})$ and its dissipation rate $(\varepsilon)$. The turbulent kinetic energy $(\mathrm{k})$ and the amount of its dissipation rate $(\varepsilon)$ are obtained from the following equations:

$$
\begin{aligned}
& \frac{\partial}{\partial \mathrm{t}}(\rho \mathrm{k})+\frac{\partial}{\partial \mathrm{x}_{\mathrm{i}}}\left(\rho \mathrm{u}_{\mathrm{i}} \mathrm{k}\right)=\frac{\partial}{\partial \mathrm{x}_{\mathrm{j}}}\left[\left(\mu+\frac{\mu_{\mathrm{t}}}{\sigma_{\mathrm{k}}}\right) \frac{\partial \mathrm{k}}{\partial \mathrm{x}_{\mathrm{j}}}\right]+\mathrm{G}_{\mathrm{k}}+\mathrm{G}_{\mathrm{b}}-\rho \varepsilon-\mathrm{Y}_{\mathrm{M}}+\mathrm{S}_{\mathrm{k}} \\
& \frac{\partial}{\partial \mathrm{t}}(\rho \varepsilon)+\frac{\partial}{\partial \mathrm{x}_{\mathrm{i}}}\left(\rho \mathrm{u}_{\mathrm{i}} \varepsilon\right)=\frac{\partial}{\partial \mathrm{x}_{\mathrm{j}}}\left[\left(\mu+\frac{\mu_{\mathrm{t}}}{\sigma_{\varepsilon}}\right) \frac{\partial \varepsilon}{\partial \mathrm{x}_{\mathrm{j}}}\right]+\mathrm{C}_{1 \varepsilon} \frac{\varepsilon}{\mathrm{k}}\left(\mathrm{G}_{\mathrm{k}}+\mathrm{C}_{3 \varepsilon} \mathrm{G}_{\mathrm{b}}\right)-\mathrm{C}_{2 \varepsilon} \rho \frac{\varepsilon^{2}}{\mathrm{k}}+\mathrm{S}_{\varepsilon}
\end{aligned}
$$

In these equations, $G_{k}$ represents the generation of turbulence kinetic energy due to the mean velocity gradients, $G_{b}$ is the generation of turbulence kinetic energy due to buoyancy, $\mathrm{Y}_{\mathrm{M}}$ represents the contribution of the fluctuating dilatation in compressible turbulence to the overall dissipation rate, $\mathrm{C}_{1 \varepsilon}, \mathrm{C}_{2 \varepsilon}$ and $\mathrm{C}_{3 \varepsilon}$ are constants. $\sigma_{\mathrm{k}}$ and $\sigma_{\varepsilon}$ are the turbulent Prandtl numbers for $\mathrm{k}$ and $\varepsilon$, respectively. $S_{k}$ and $S_{\varepsilon}$ are user-defined source terms. The values of the constants used in the Standard k- $\varepsilon$ model are given in Table 1 (Fluent, 2017).
Table 1. The values of the constants used in the standard $\mathrm{k}-\varepsilon$ model

Tablo 1. Standart $k$ - $\varepsilon$ model'de kullanılan sabitler

\begin{tabular}{cc}
\hline Constant & Value \\
\hline $\mathrm{C}_{1 \varepsilon}$ & 1.44 \\
$\mathrm{C}_{2 \varepsilon}$ & 1.92 \\
$\mathrm{C}_{\mu}$ & 0.09 \\
$\sigma_{\mathrm{k}}$ & 1.0 \\
$\sigma_{\varepsilon}$ & 1.3 \\
\hline
\end{tabular}


Turbulent heat flux in the conservation equation of energy $\left(\overline{\mathrm{u}_{1} \mathrm{t}}\right)$ defined as:

$\left(\overline{\mathrm{u}_{\mathrm{j}} \mathrm{t}}\right)=\alpha_{\mathrm{t}} \frac{\partial \mathrm{T}}{\partial \mathrm{x}_{\mathrm{j}}}$

where $\alpha_{\mathrm{t}}$ is turbulence heat dissipation coefficient and defined as:

$\alpha_{\mathrm{t}}=\frac{v_{\mathrm{t}}}{\mathrm{Pr}_{\mathrm{t}}}$

where $\operatorname{Pr}_{t}$ is turbulence Prandtl number.

In the calculation of Nusselt number $(\mathrm{Nu})$ and Reynolds number ( $\mathrm{Re})$ the following equations were used:

$\mathrm{Nu}=\frac{\mathrm{hd}}{\mathrm{k}}$
$\mathrm{Re}=\frac{\mathrm{vd}}{v}$

In these equations, $\mathrm{d}$ is the tube diameter, $\mathrm{k}$ is the heat conduction coefficient, $h$ is the local heat transfer coefficient, $\mathrm{V}$ is the average air velocity and $v$ is the kinematic viscosity.

The hydraulic power $\left(\mathrm{P}_{\text {hydr }}\right)$ required for the water to circulate in the tube at the desired flow rate is obtained from:

$\mathrm{P}_{\text {hydr }}=\Delta \mathrm{p} \dot{V}$

where $\Delta \mathrm{p}$ and $\dot{V}$ are pressure loss and flow rate, respectively.

Figure 1 shows the designed channeled waterblock heat sink configurations. As shown from the figure, in Type A, water enters to one channel and passes six times in the channels and exits from the parallel side of the channel. In Type B, water enters to three channel and exits from the parallel side of the three channels. In Type $\mathrm{C}$, water enters to six channel and exits from the opposite side of the six channels. In Type D, water enters via two channels on two parallel sides and exits from two channels in the middle. As mentioned above, the air enters through a rectangular cross-section and exits from its opposite surface.

To solve the problem, the geometry must be meshed in CFD. To obtain a good mesh structure, values such as element quality, orthogonal quality and skewness are desired to be close to the values of 1,1 and 0 , respectively (Fluent, 2017). In addition to these features, mesh size is also an important parameter. Reducing the mesh size usually has a positive effect on the quality of the mesh structure, but this will increase the number of elements and nodes in the mesh structure, thus extending the time required for the solution. In this context, the optimal mesh size must be found. In this study, coarse, medium and fine mesh structures were tested to determine the grid-independent solution. The tetrahedral element was employed in the meshing process to obtain a good mesh of geometries where folds are intense. The medium and fine mesh structures were in acceptable ranges in terms of element quality, average skewness and orthogonal quality. Also, the results of medium and fine mesh structures were close to each other so the medium mesh structure was used in this study to save computation time. The medium mesh structure of geometry is shown in Figure 2. Finer computational grids were set near the wall and $y^{+}$ value was less than 2 . This mesh has a total 10815227 number of elements and 1815073 nodes. The properties of the mesh structures and results of water outlet temperatures are shown in Table 2, which were calculated at a water inlet velocity of $0.5 \mathrm{~m} / \mathrm{s}$. The properties of materials used in the analysis are shown in Table 3.

Table 2. Properties of mesh structures used in the analysis

Tablo 2. Analizlerde kullanılan mesh yapılarının özellikleri

\begin{tabular}{|c|c|c|c|c|c|c|c|c|c|c|c|c|}
\hline & \multicolumn{3}{|c|}{ Type A } & \multicolumn{3}{|c|}{ Type B } & \multicolumn{3}{|c|}{ Type C } & \multicolumn{3}{|c|}{ Type D } \\
\hline & Coarse & Medium & Fine & Coarse & Medium & Fine & Coarse & Medium & Fine & Coarse & Medium & Fine \\
\hline $\begin{array}{l}\text { Average } \\
\text { skewness }\end{array}$ & 0.28 & 0.25 & 0.23 & 0.28 & 0.25 & 0.24 & 0.28 & 0.25 & 0.24 & 0.28 & 0.24 & 0.23 \\
\hline $\begin{array}{c}\text { Average } \\
\text { orthogonal } \\
\text { quality }\end{array}$ & 0.71 & 0.75 & 0.76 & 0.71 & 0.74 & 0.75 & 0.71 & 0.74 & 0.75 & 0.71 & 0.75 & 0.76 \\
\hline $\begin{array}{l}\text { Average } \\
\text { element } \\
\text { quality }\end{array}$ & 0.79 & 0.82 & 0.83 & 0.79 & 0.82 & 0.83 & 0.79 & 0.82 & 0.83 & 0.79 & 0.82 & 0.83 \\
\hline $\begin{array}{c}\text { Node } \\
\text { number }\end{array}$ & 353028 & 1837309 & 3611521 & 352623 & 1815073 & 3407737 & 344192 & 1827020 & 3412037 & 348751 & 1761694 & 3802178 \\
\hline $\begin{array}{l}\text { Element } \\
\text { number }\end{array}$ & 2081144 & 10931030 & 21477170 & 2077554 & 10815227 & 20291542 & 2031738 & 10894757 & 20313286 & 2055838 & 10488333 & 22565133 \\
\hline $\begin{array}{c}\text { Outlet } \\
\text { temperature }\end{array}$ & 73.2 & 70.7 & 69.5 & 73.6 & 70.8 & 69.5 & 73.3 & 70.9 & 69.8 & 73.6 & 71.3 & 69.8 \\
\hline
\end{tabular}



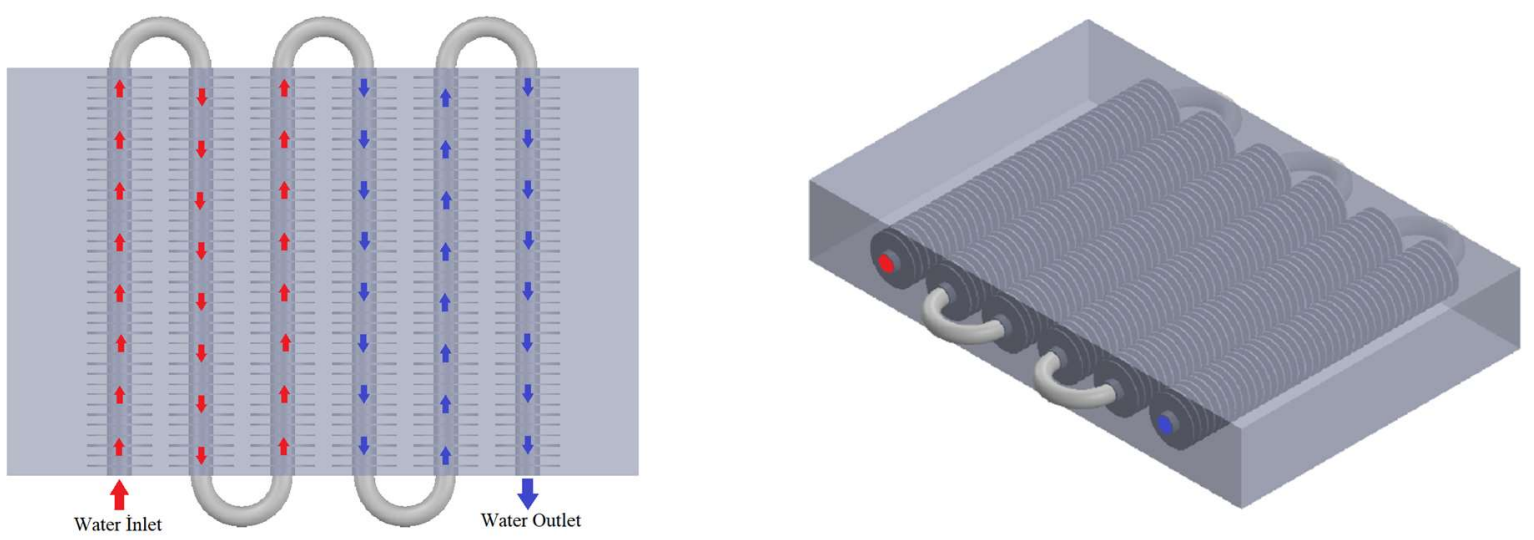

Type-A
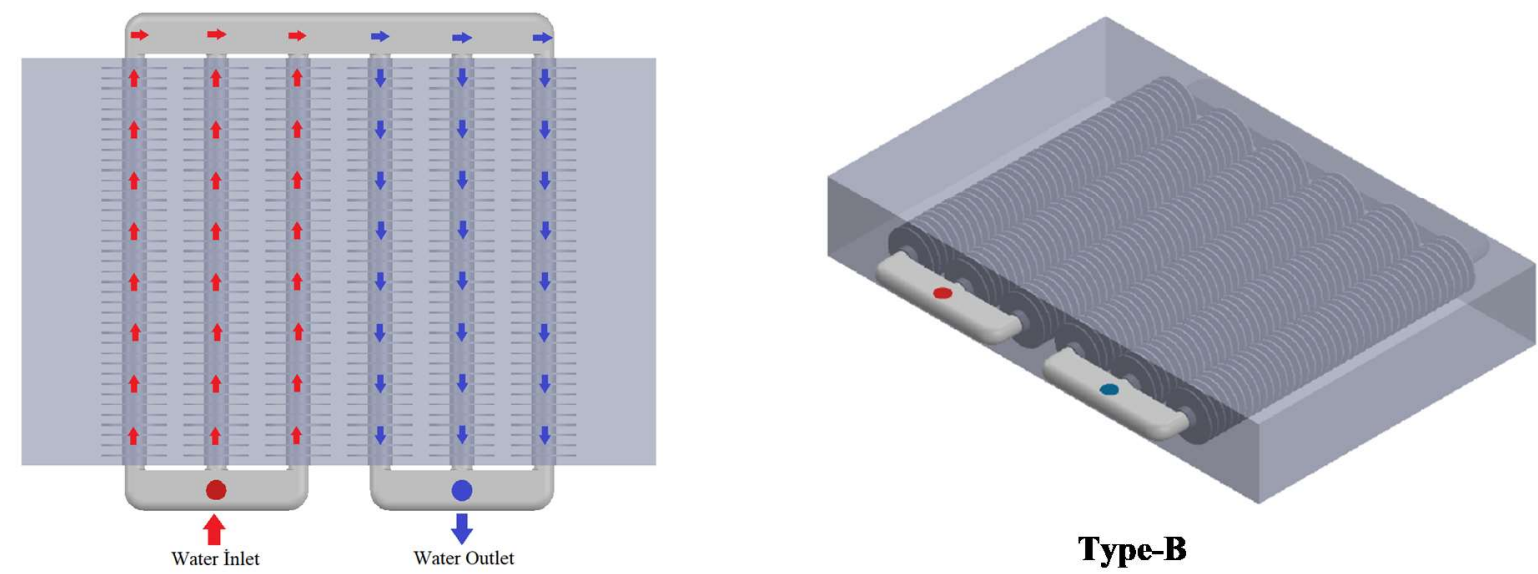

Type-B
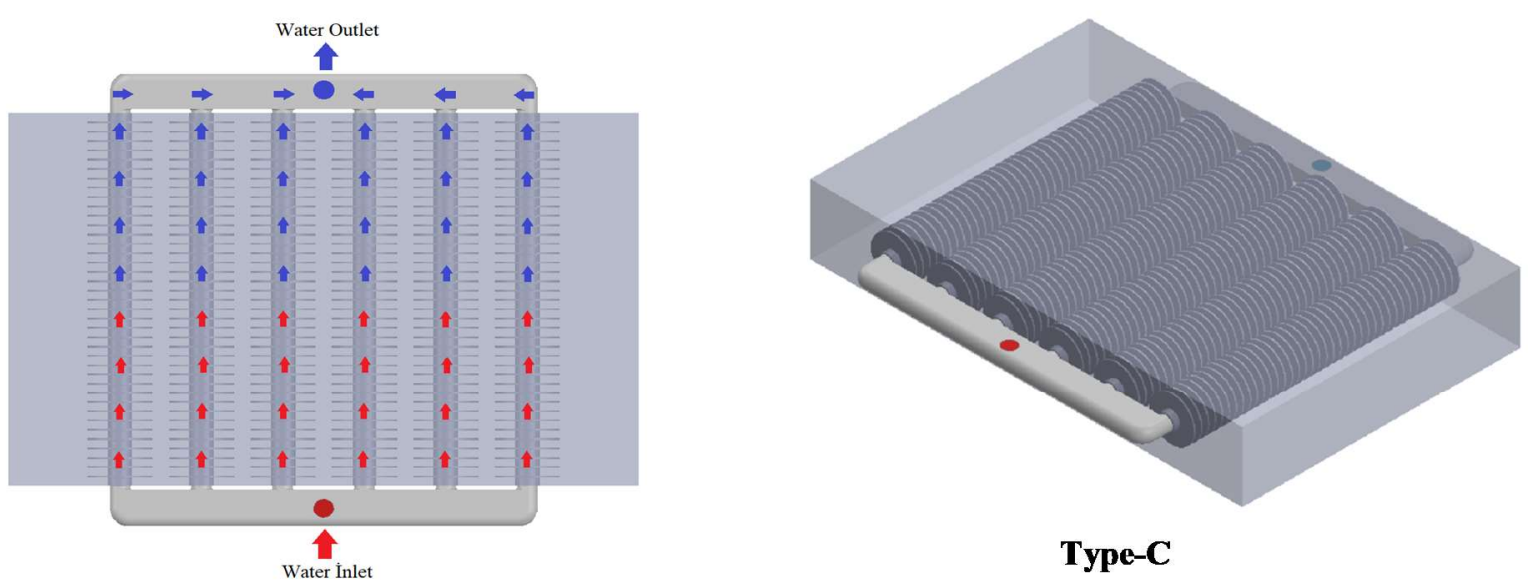

Type-C
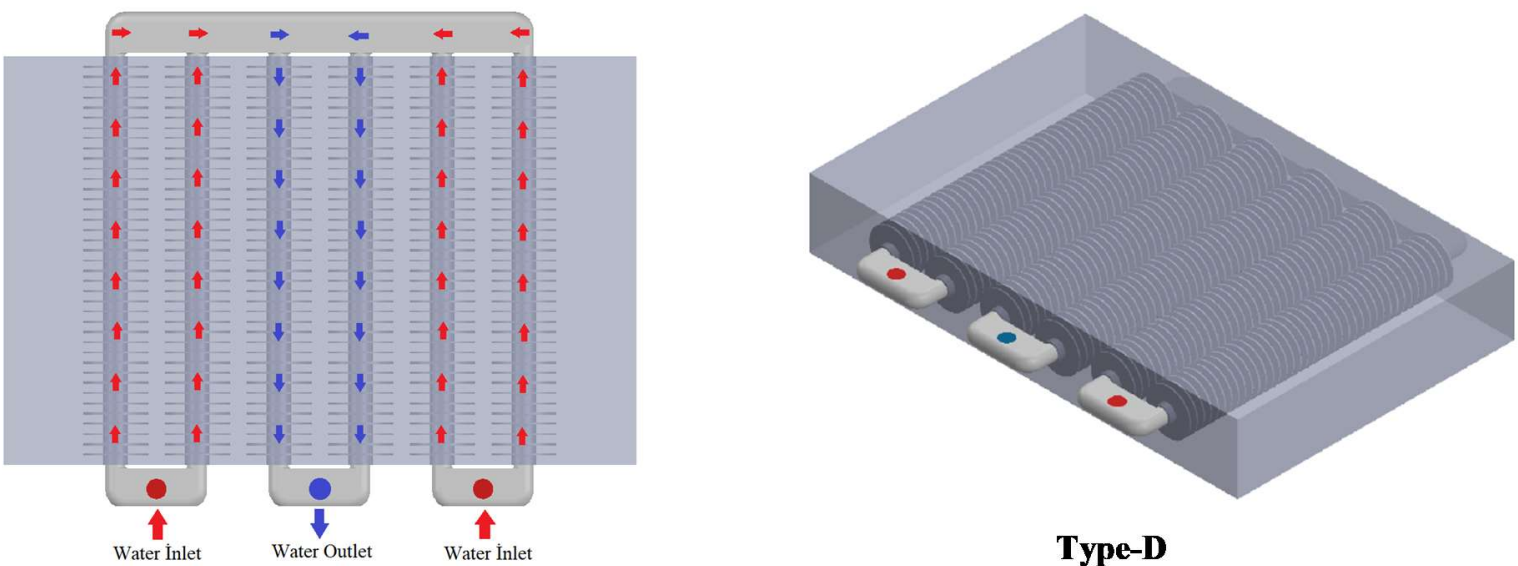

Type-D

Figure 1. The flow channels (left) and isometric view of the channel heat sinks (right) Şekil 1. Kanallı ısı alıcıların akış kanalları (solda) ve izometrik (sağda) görünümleri 


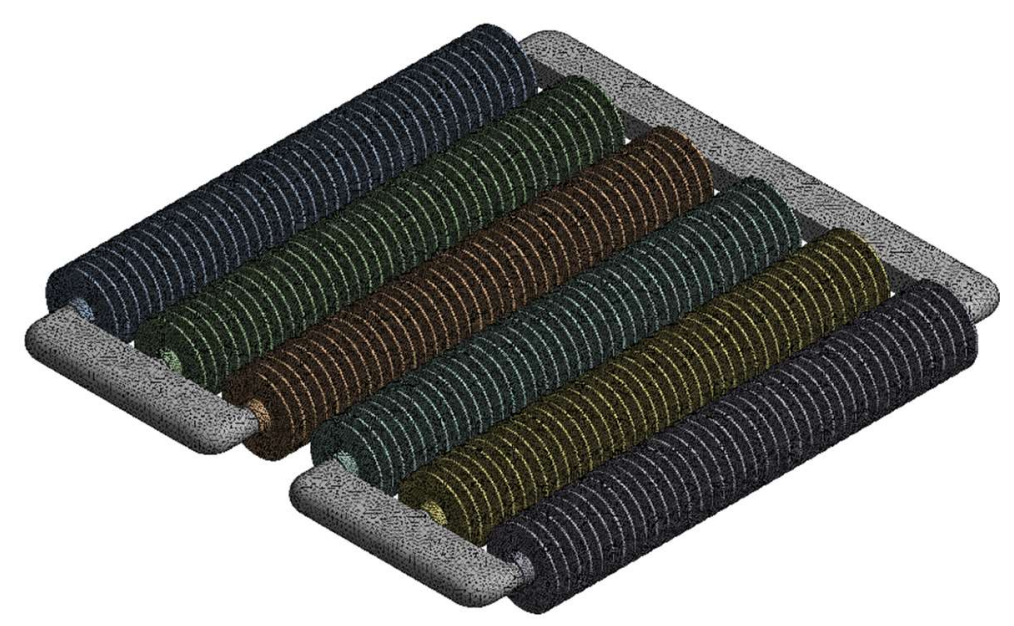

Figure 2. The mesh structure of Type-B channel heat sink. Şekil 2. Tip-B kanallı ısı alıcının ăg yapısı

Table 3. Properties of the materials used in the analysis Tablo 3. Analizlerde kullanılan materyallerin özellikleri

\begin{tabular}{llll}
\hline Names & Thermal conductivity & Density & Specific heat \\
& $\lambda$ & $\rho$ & $\begin{array}{l}c_{p} \\
\left(W \cdot \mathrm{m}^{-1} \cdot \mathrm{K}^{-1}\right)\end{array}$ \\
& $\left(\mathrm{kg} / \mathrm{m}^{3}\right)$ & $(\mathrm{j} / \mathrm{kg} \cdot \mathrm{K})$ \\
\hline Heat sink & 202.4 & 2719 & 871 \\
Air & 0.0242 & 1.225 & 1006.43 \\
Water & 0.6 & 998.2 & 4182 \\
\hline
\end{tabular}

To numerically analyze the designed heat sink configurations, three average inlet water velocities of $0.25 \mathrm{~m} / \mathrm{s}, 0.5 \mathrm{~m} / \mathrm{s}$ and $1 \mathrm{~m} / \mathrm{s}$ were chosen by holding the air velocity constant at $6 \mathrm{~m} / \mathrm{s}$. While calculating the Reynolds number, the average velocity values at the inlet were based on both the air and water sides. In this case, the flow on both sides became turbulent. Numerical calculations were made with ANSYS Fluent CFD program. The outlet and inlet sections were defined as pressure outlet and velocity inlet, respectively. The water and air inlet temperatures were $80{ }^{\circ} \mathrm{C}$ and $25^{\circ} \mathrm{C}$, respectively. Atmospheric pressure was selected at water and air outlets. The coupled wall condition was adopted to provide conjugate heat transfer at interfaces between liquid and solid domains. Four side surfaces of the air domain and surfaces of the water channels outside the air domain were selected as adiabatic walls. The boundary conditions of the channel heat sink were shown in Figure 3. Steady-state pressure-based solver were employed for numerical solution. Standart k- $\varepsilon$ model was used as turbulence model.

In all solutions, SIMPLE algorithm was used to solve the discretized equations of pressure-velocity coupling. The standard scheme was used to discretize pressure and the first-order upwind scheme was used to discretize momentum, turbulent kinetic energy and turbulent dissipation rate. For all dependent variables, the convergence criteria for the residuals were set to $10^{-6}$. 

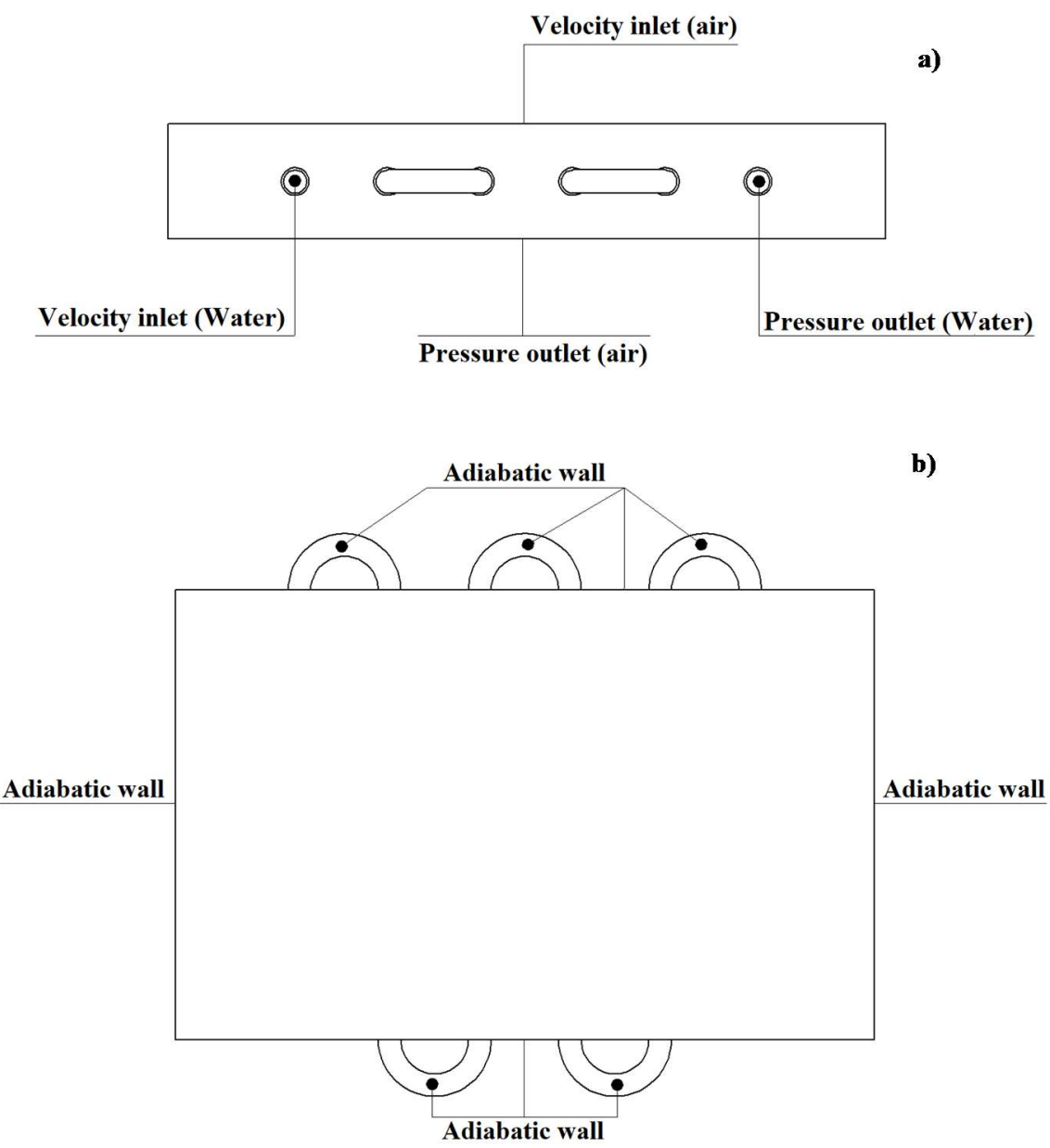

Figure 3. The boundary conditions of the channel heat sink, a) front view, b) top view Şekil 3. Kanallı ısı alıclların sinır şartları, a)ön görünüm, b) üst görünüm

\section{Results and discussions}

\section{Bulgular ve tartışma}

This work carried out calculations for 12 different situations using four different geometries (Type-A, Type-B, Type-C, Type-D), and three different average inlet water velocities $(0.25 \mathrm{~m} / \mathrm{s}, 0.5 \mathrm{~m} / \mathrm{s}$ and $1 \mathrm{~m} / \mathrm{s}$ ). The average inlet velocities of $0.25,0.5$, $1 \mathrm{~m} / \mathrm{s}$ represent the Reynolds numbers of 2500 , 5000,10000 , respectively. Figure 4 shows the temperature contours for four different geometries at water velocity value of $0.5 \mathrm{~m} / \mathrm{s}$. Since the other velocity values were similar, these results were not shown both here and in the contour results from now on.

It can be said that when the Reynolds number decreased, the water outlet temperatures also decreased, as water is exposed to air for a longer time at low flow velocity. In all cases, the average temperatures throughout the channels were in the range of $70{ }^{\circ} \mathrm{C}-80^{\circ} \mathrm{C}$.

To compare the configurations with each other it is difficult to make a precise comment from these contours. A more precise comparison will be made with the graphs given depending on the outlet temperature values in the following section.

Figure 5 shows the velocity streamlines contours of four different geometries at a water velocity value of $0.5 \mathrm{~m} / \mathrm{s}$. Increasing the water velocities increased eddies in all cases. Also, it is seen that eddies increase with the increase in the number of elbows in the configurations. While the velocity and mass flow per water channel remained constant in Type-A, in Type-B and Type-C dropped to onethird and to one-sixth, respectively. The same parameters in Type-D dropped to one-fourth at the inlet and to half at outlet section. 

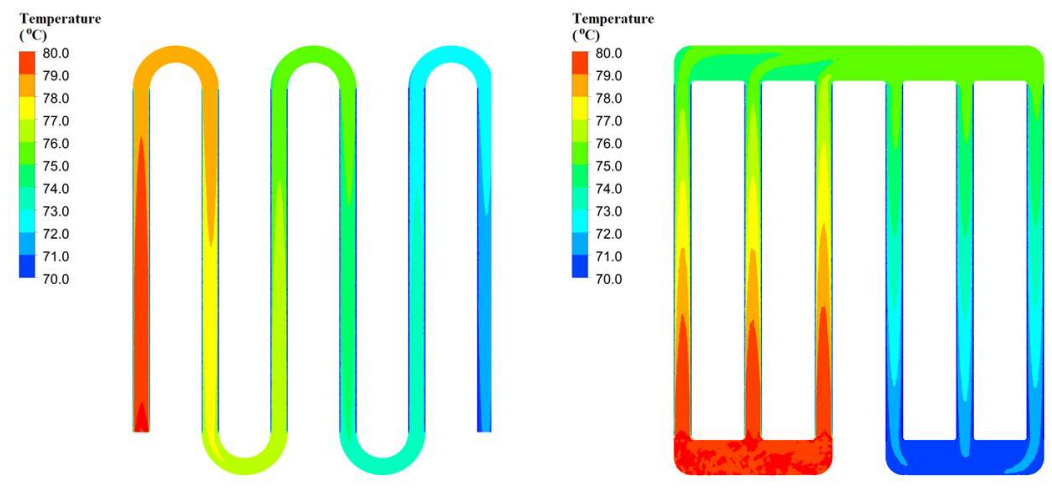

a)

b)

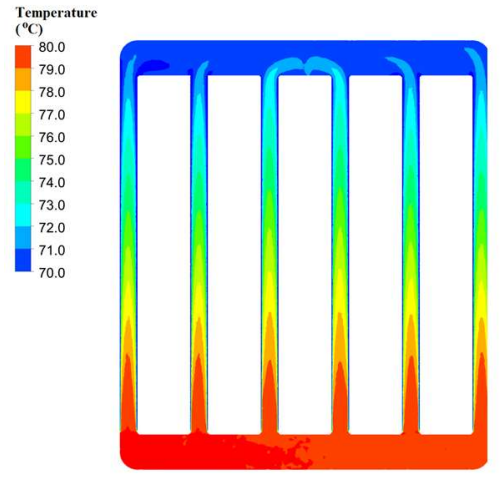

c)

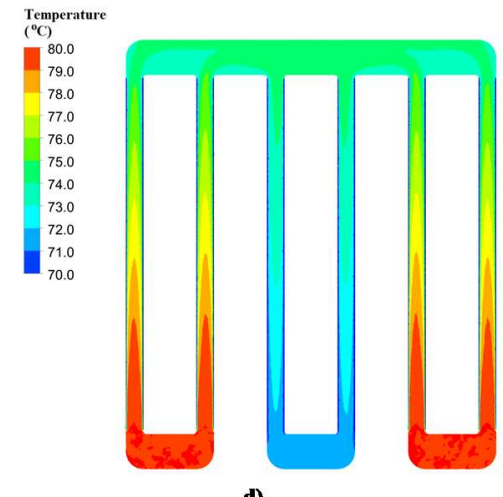

Figure 4. Temperature contours for different geometries at water velocity value of 0.5 $\mathrm{m} / \mathrm{s}$, a) Type-A, b) Type-B, c) Type-C, d) Type-D

Şekil $4.0 .5 \mathrm{~m} / \mathrm{s}$ su hızı değerinde farklı geometriler için sicaklık konturlarl, a) Tip-A, b) Tip-B, c) Tip-C, d) Tip-D
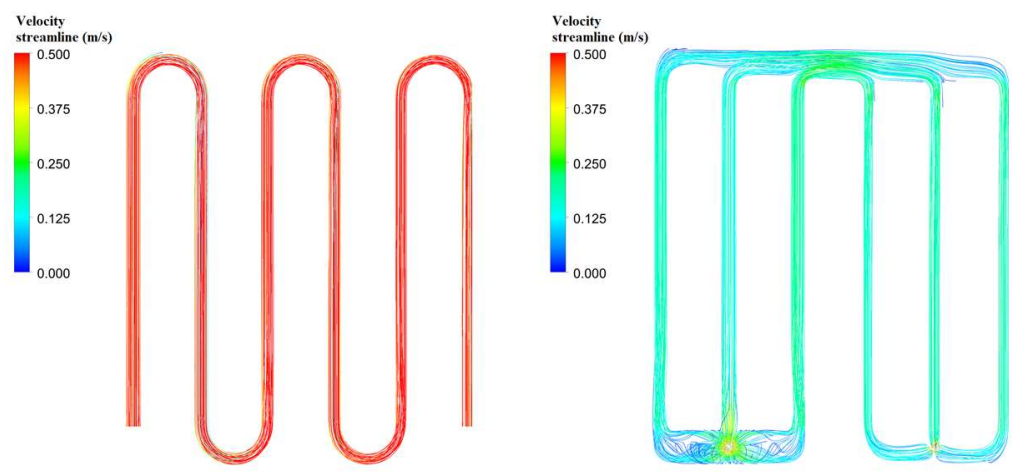

a)

b)
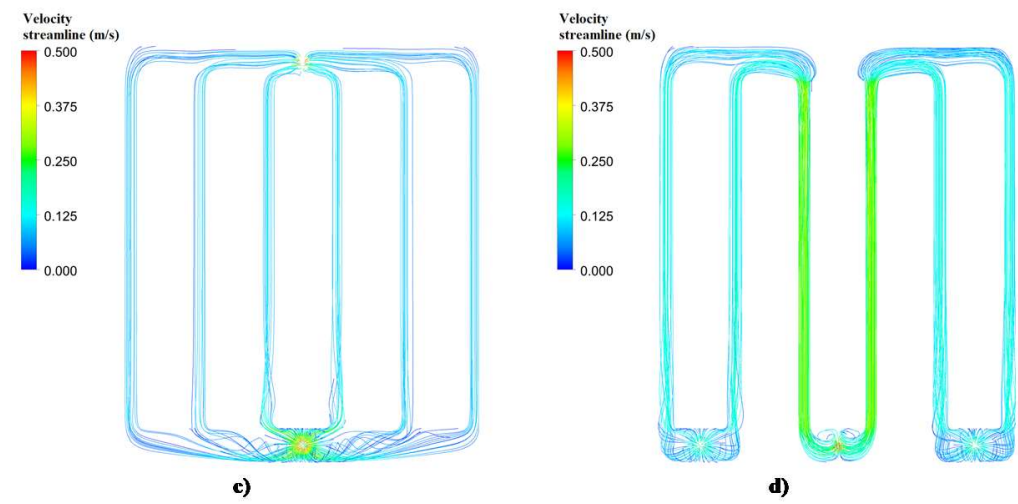

Figure 5. Velocity streamlines for different geometries at water velocity value of $0.5 \mathrm{~m} / \mathrm{s}$, a) Type-A, b) Type-B, c) Type-C, d) Type-D

Şekil 5. $0.5 \mathrm{~m} / \mathrm{s}$ su hızı değerinde farklı geometriler için hız akım çizgileri, a) Tip-A, b) Tip-B, c) Tip-C, d) Tip-D 
Increase in heat transfer generally causes an increase in pressure loss. This situation is shown in Figure 6. Pressure contour views were taken from the middle cross-section, and the highest pressures indicated on the scale occurred at the corners of the three-dimensional geometries. As seen from this figure, Type-A has the highest pressure loss with a value of $1538 \mathrm{~Pa}$. The increase in the number of passes in the pipe increased the pressure loss. The other geometries had similar pressure loss, and the lowest pressure loss is obtained in the Type-C geometry with a value of $250 \mathrm{~Pa}$.

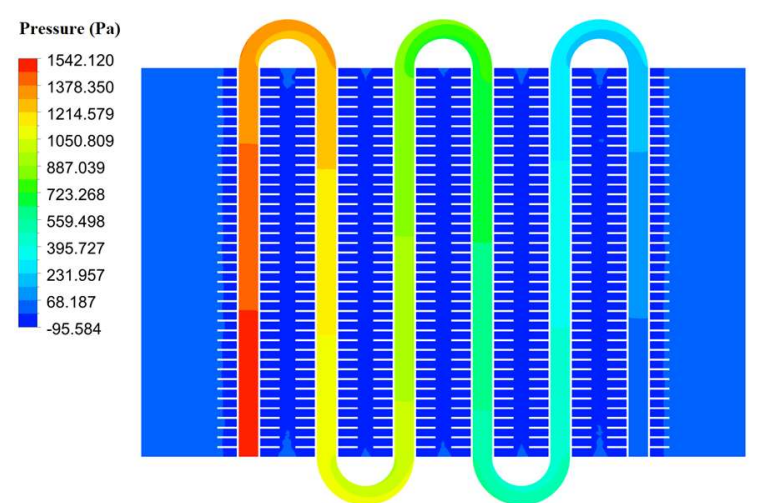

a)

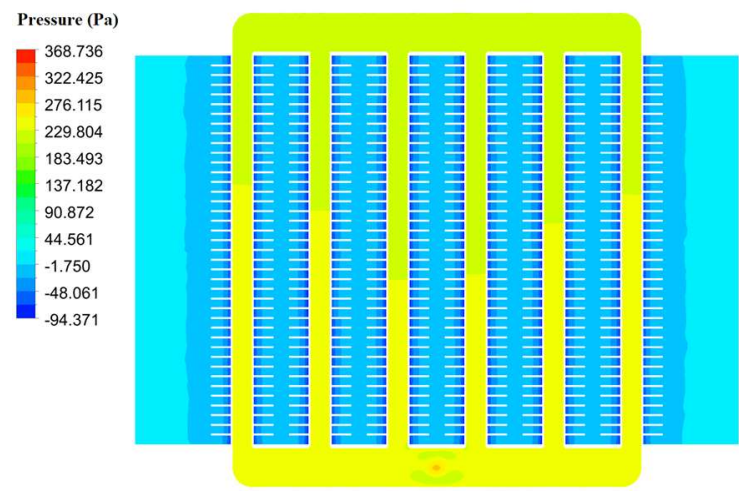

c)

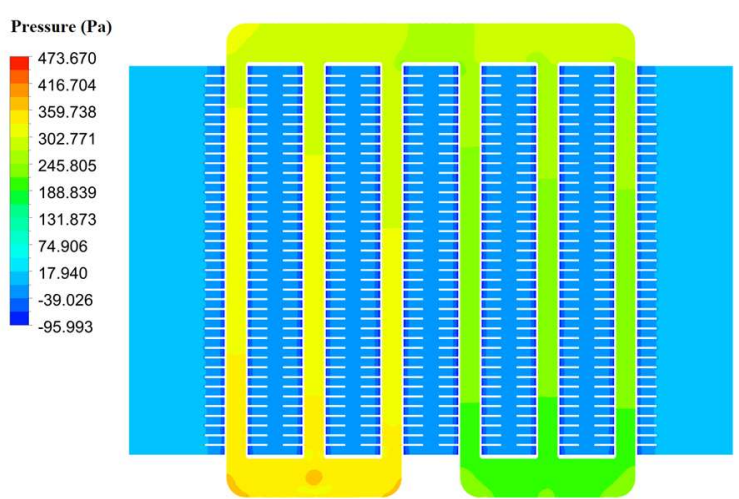

b)

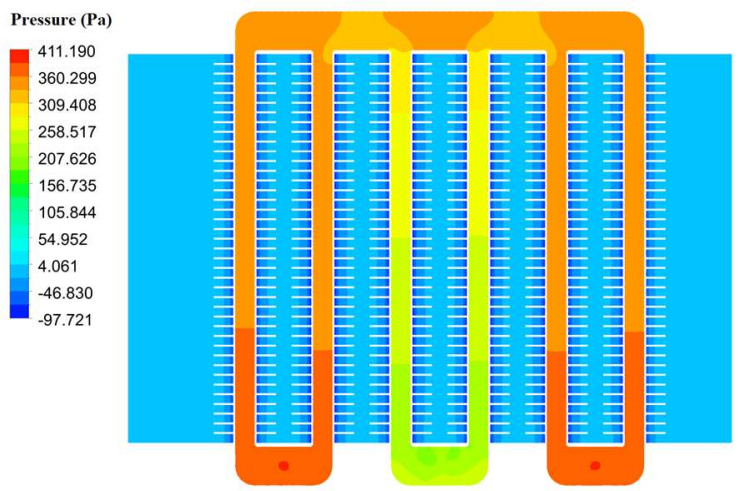

d)

Figure 6. Pressure contours for different geometries at water velocity value of $0.5 \mathrm{~m} / \mathrm{s}$, a) Type-A, b) Type-B, c) Type-C, d) Type-D

Şekil 6. $0.5 \mathrm{~m} / \mathrm{s}$ su hızı değerinde farklı geometriler için basınç konturları, a) Tip-A, b) Tip-B, c) Tip-C, d) Tip-D

Graphics of the analysis results of the channel water block heat sink system were given in Figure 7. Some terms were explained following. The hydraulic power means that the required power to overcome pressure losses, the outlet temperature means the water outlet temperature from the tube, the temperature difference means the difference between water inlet and outlet temperatures.

As can be seen from Figure 7.a, in all configurations, the outlet temperatures of water were very close to each other which were in the range of $63-65{ }^{\circ} \mathrm{C}$ for $\mathrm{Re}=2500,70-72{ }^{\circ} \mathrm{C}$ for $\mathrm{Re}=5000$ and $74-76{ }^{\circ} \mathrm{C}$ for $\mathrm{Re}=10000$. Among all configurations, Type-A has the minimum outlet temperature with a value of $63.40^{\circ} \mathrm{C}$ for $\mathrm{Re}=2500$, $70.77{ }^{\circ} \mathrm{C}$ for $\mathrm{Re}=5000$ and $74.85^{\circ} \mathrm{C}$ for $\mathrm{Re}=10000$. Type-D has slightly higher outlet temperature among all models with a value of $64.40{ }^{\circ} \mathrm{C}$ for $\mathrm{Re}=2500,71.36{ }^{\circ} \mathrm{C}$ for $\mathrm{Re}=5000$ and $75.41{ }^{\circ} \mathrm{C}$ for $\mathrm{Re}=10000$. The highest temperature difference in relation to the outlet temperatures also occurred in Type-A configuration which is $16.60{ }^{\circ} \mathrm{C}$ for $\mathrm{Re}=2500,9.23{ }^{\circ} \mathrm{C}$ for $\mathrm{Re}=5000$ and $5.15^{\circ} \mathrm{C}$ for $\mathrm{Re}=10000$. As shown in Figure 7.b, the temperature difference values were very close to each other which were in the range of $15-17^{\circ} \mathrm{C}$ for $\mathrm{Re}=2500,8-10{ }^{\circ} \mathrm{C}$ for $\mathrm{Re}=5000$ and $4-6{ }^{\circ} \mathrm{C}$ for $\mathrm{Re}=10000$.

As the water velocity increased, the outlet temperature also increased. It is difficult to compare configurations as the values in terms of outlet temperatures which are very close to each other in all types. Therefore, to compare the heat transfer performances, it is necessary to look at the 
heat transfer rate to air. Figure 7.d shows the variation of heat transfer rate to air with Reynolds number. According to this figure, Type-A showed better heat transfer performance than other models with the value of $1346 \mathrm{~W}$ for $\mathrm{Re}=2500,1500 \mathrm{~W}$ for $\mathrm{Re}=5000$ and $1675 \mathrm{~W}$ for $\mathrm{Re}=10000$. The worst performance occurred in Type-D configuration. According to the heat transfer rate to air, the best cooling performance can be listed from high to low as follows: types $\mathrm{A}, \mathrm{B}, \mathrm{C}$ and $\mathrm{D}$, respectively.

The maximum pressure difference was obtained in Type-A geometry with a value of nearly $3500 \mathrm{~Pa}$ at Reynolds number value of 10000 as shown in Figure 7.e. Type-A was followed by Type-D, Type-B and Type-C geometries. The increase in pressure differences means an increase in the pumping power. In this sense, the most power consumption occurred in the Type-A configuration (Figure 7.f) with a value of $275 \mathrm{~mW}$ at $\mathrm{Re}=10000$, which had the highest pressure difference. In all models, at $\mathrm{Re}=2500$, power consumptions were very low and were in the range of $1-13 \mathrm{~mW}$. Based on these results, it was inferred that water passes had a significant effect on pump power.

In all analyses, pressure difference, outlet temperature, hydraulic power, heat transfer to air increased proportionally by increasing Reynolds number while temperature difference and total thermal resistance decreased.
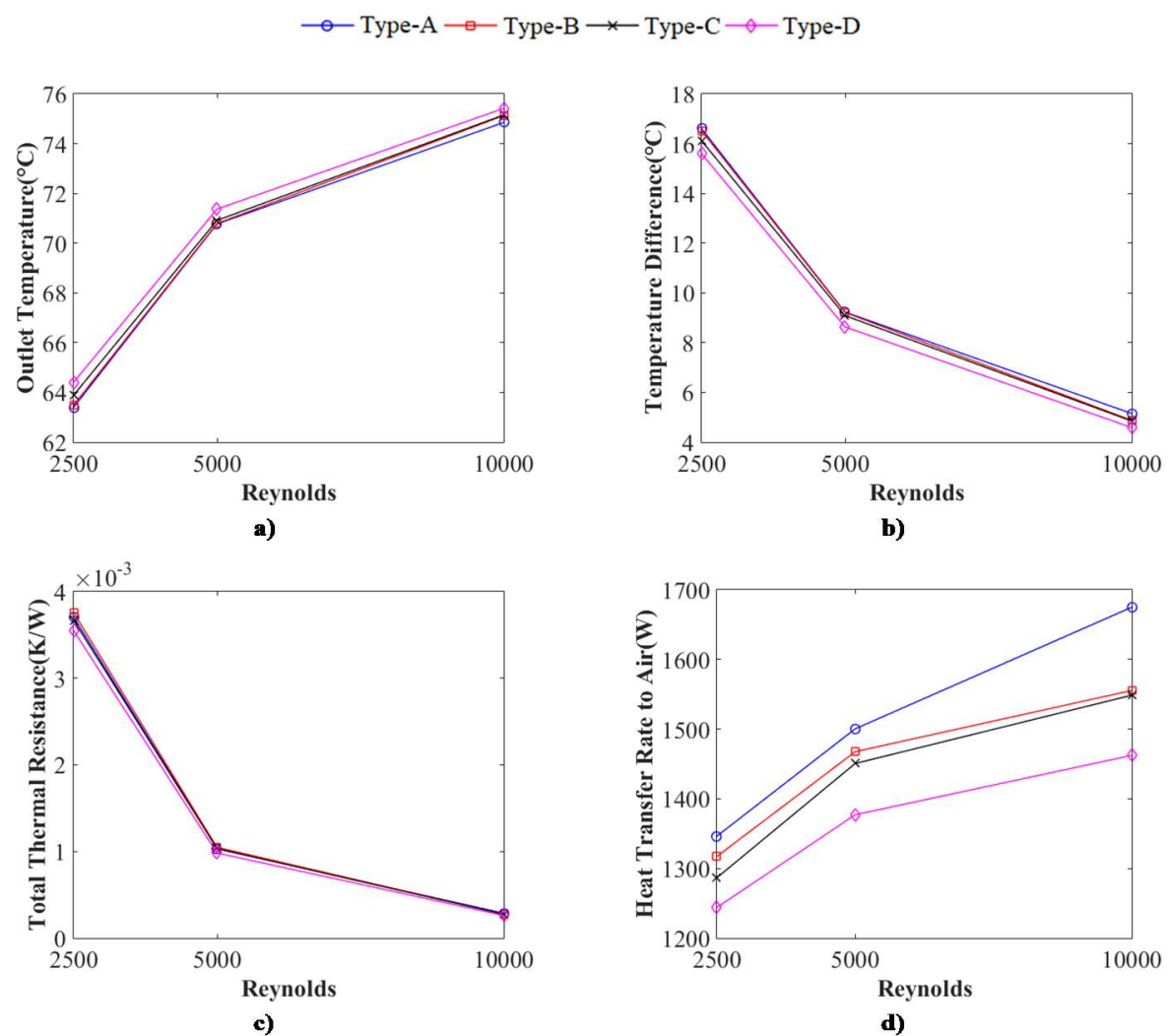

b)
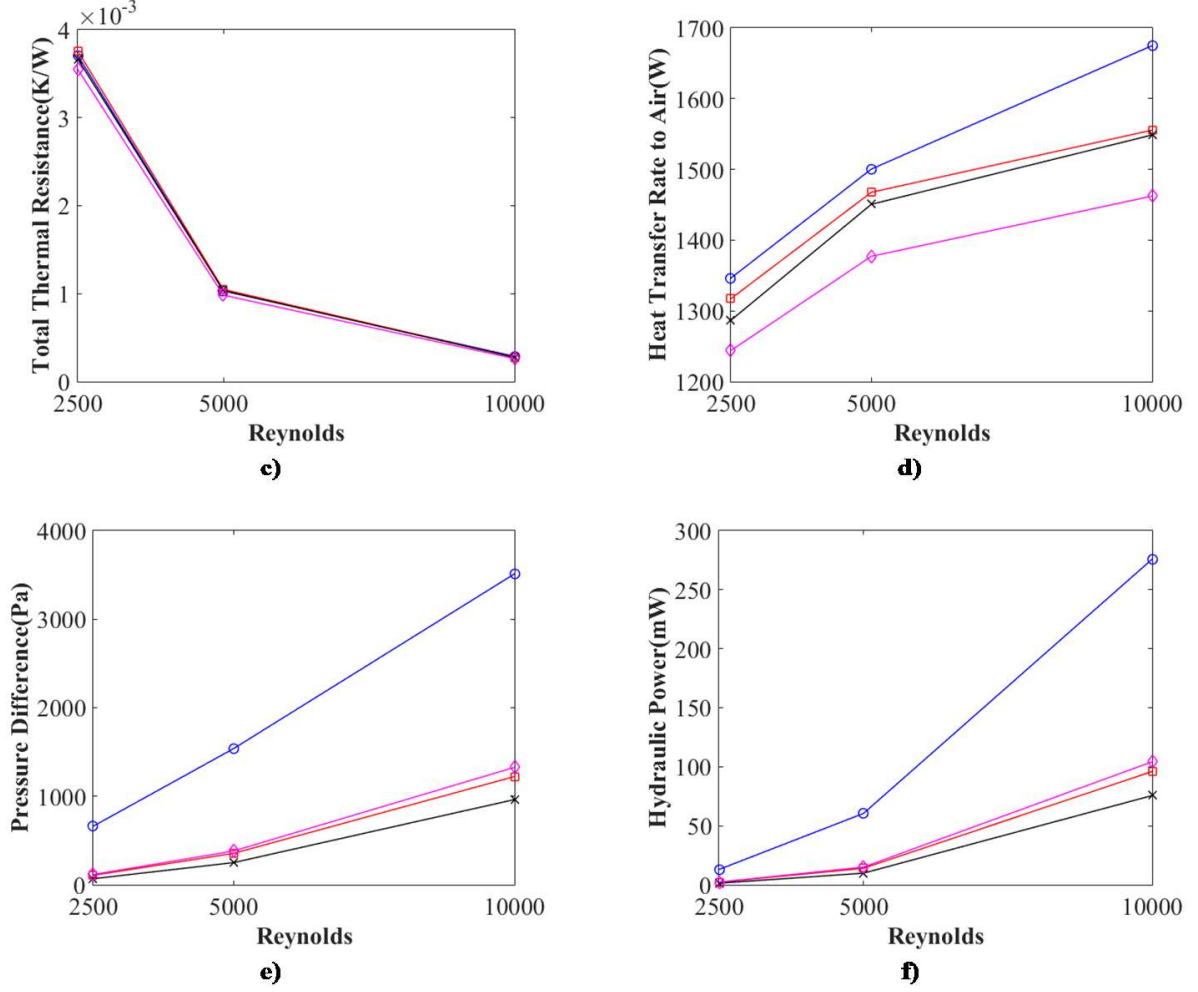

Figure 7. a) Outlet temperature, b) temperature difference, c) total thermal resistance, d) heat transfer to air, e) pressure difference, f) hydraulic power in relation to Reynolds number

Şekil 7. a) Çıkıls sicaklı̆̆l, b) sıcaklık farkl, c) toplam ısll direnç, d) havaya ısı transferi, e) basınç farkl, f) Reynolds sayısina göre hidrolik güç 
In all geometries, the highest heat transfer occurred where the highest pressure drop occurred, and this situation was given in Figure 8. In the Type-A model, where the highest pressure drop was obtained, when the pressure loss was $660 \mathrm{~Pa}, 1540$ $\mathrm{Pa}$ and $3500 \mathrm{~Pa}$, the heat transfer rate to air was $1346 \mathrm{~W}, 1500 \mathrm{~W}, 1675 \mathrm{~W}$, respectively.

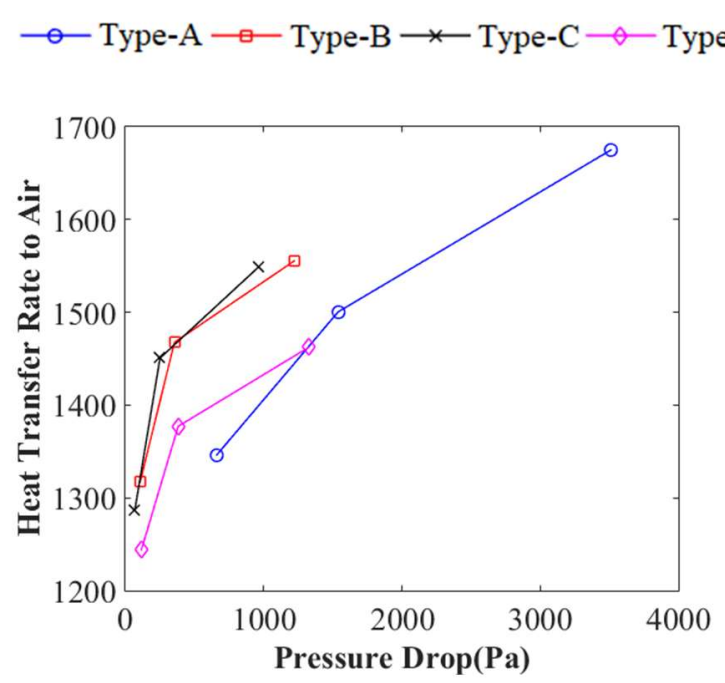

Figure 8. The increase in heat transfer in relation to the increase in pressure drop

Şekil 8. Basınç düşüşündeki artışa bağlı olarak ısı transferindeki artış

\section{Conclusions}

\section{Sonuçlar}

In this study, thermal performance of water-cooled heat sink configurations at different water velocities $(0.25 \mathrm{~m} / \mathrm{s}, 0.5 \mathrm{~m} / \mathrm{s}$ and $1 \mathrm{~m} / \mathrm{s})$ was investigated numerically. This study showed that increasing the water velocities increased the pressure difference, outlet temperature, heat transfer rate to air and hydraulic power in all analyses. The outlet temperature values were close to each other in all type of configurations which were in the range of $63-65^{\circ} \mathrm{C}$ for $\mathrm{Re}=2500,70-72$ ${ }^{\circ} \mathrm{C}$ for $\mathrm{Re}=5000$ and $74-76{ }^{\circ} \mathrm{C}$ for $\mathrm{Re}=10000$ but it was slightly higher in Type-D which is $64.40^{\circ} \mathrm{C}$ for $\mathrm{Re}=2500,71.36^{\circ} \mathrm{C}$ for $\mathrm{Re}=5000$ and $75.41^{\circ} \mathrm{C}$ for $\mathrm{Re}=10000$. Among all configurations, Type-A has the minimum outlet temperature with a value of $63.40{ }^{\circ} \mathrm{C}$ for $\mathrm{Re}=2500,70.77{ }^{\circ} \mathrm{C}$ for $\mathrm{Re}=5000$ and $74.85{ }^{\circ} \mathrm{C}$ for $\mathrm{Re}=10000$. The highest temperature difference in relation to the outlet temperatures also occurred in Type-A configuration which is $16.60^{\circ} \mathrm{C}$ for $\mathrm{Re}=2500,9.23$ ${ }^{\circ} \mathrm{C}$ for $\mathrm{Re}=5000$ and $5.15{ }^{\circ} \mathrm{C}$ for $\mathrm{Re}=10000$. The cooling performance can be better understood by looking at the heat transfer rate to air. According to this result, Type-A had the best cooling performance with a value of $1346 \mathrm{~W}$ for $\mathrm{Re}=2500$,
$1500 \mathrm{~W}$ for $\mathrm{Re}=5000$ and $1675 \mathrm{~W}$ for $\mathrm{Re}=10000$, while Type-D had the worst performance with the value of $1243 \mathrm{~W}$ for $\mathrm{Re}=2500,1377 \mathrm{~W}$ for $\mathrm{Re}=5000$ and $1462 \mathrm{~W}$ for $\mathrm{Re}=10000$.

The maximum pressure difference was obtained in Type-A geometry with a value of nearly $3500 \mathrm{~Pa}$ at Reynolds number value of 10000 . The increase in pressure differences means an increase in the pumping power. In this context, the most power consumption occurred in the Type-A configuration (Figure 7.f) with a value of $275 \mathrm{~mW}$ at $\mathrm{Re}=10000$ which had the highest pressure difference. In all models, at $\mathrm{Re}=2500$, power consumptions were very low and were in the range of $1-13 \mathrm{~mW}$.

Generally, it was observed that the effect of different water passes on heat transfer was limited but significantly affects the pump power that provides the flow of water. Moreover, pump power emerges disadvantages, such as larger pump, higher operating temperature, and shorter pump life. As a result, the use of Type-B was found more convenient due to the advantage of pump power and water inlet-outlet positions. In Type-A design, it was concluded that since a breakdown in one of the channels would make the whole system inoperable and the highest pump power was in this design, it should be preferred less than the others. The results of this study could provide valuable information for CPU manufacturers that can help improve the future design.

The calculations performed in this study give a numerical estimation of the water-cooled heat sinks. Hence, there is much scope for further research to understand exactly the working of the equipment. Without experimental validation, the CFD results will not be completely sufficient. Therefore, in future studies, the validation of the CFD results with experimental data will be beneficial. In this context, various numerical models could be validated with the measured experimental data.

\section{Author contribution \\ Yazar katkısı}

Seyda Özbektaş (\%35): Investigation, Software, Calculations, Validation, Writing- Original draft preparation

Bilal Sungur (\%35): Investigation, Methodology, Validation, , Reviewing and Editing

Bahattin Topaloglu (\%30): Conceptualization, Methodology, Validation, Reviewing and Editing. 


\section{Declaration of ethical code Etik beyanı}

The authors of this article declare that the materials and methods used in this study do not require ethical committee approval and/or legal-specific permission.

\section{Conflicts of interest}

Çıkar çatışması beyanı

The authors declare that there is no conflict of interest.

\section{References}

Kaynaklar

Adams, T. M., Abdel-Khalik, S. I., Jeter, S. M., \& Qureshi, Z. H. (1998). An experimental investigation of single-phase forced convection in microchannels. International Journal of Heat and Mass Transfer, 41(6), 851-857. https://doi.org/https://doi.org/10.1016/S00179310(97)00180-4

Choi, J. T., Kwon, O. K., \& Cha, D. A. (2011). A numerical study of the heat transfer and fluid flow of micro-channeled water block for computer CPU cooling. Journal of Mechanical Science and Technology, 25(10), 2657. https://doi.org/10.1007/s12206-011-0616-4

Chung, Y. M., \& Luo, K. H. (2002). Unsteady heat transfer analysis of an impinging jet. Journal of Heat Transfer, 124(6), 1039-1048. https://doi.org/10.1115/1.1469522

Conrad, M., Diatlov, A., \& De Doncker, R. W. (2015). Purpose, potential and realization of chipattached micro-pin fin heat sinks. Microelectronics Reliability, 55(9), 1992-1996. https://doi.org/https://doi.org/10.1016/j.microrel .2015 .07 .007

Cova, P., Delmonte, N., Giuliani, F., Citterio, M., Latorre, S., Lazzaroni, M., \& Lanza, A. (2013). Thermal optimization of water heat sink for power converters with tight thermal constraints. Microelectronics Reliability, 53(9), 1760-1765. https://doi.org/https://doi.org/10.1016/j.microrel .2013 .07 .035

Fluent Incorporated. (2017). Fluent User's Guide. http://users.abo.fi/rzevenho/ansys $\% 20$ fluent $\% 20$ $18 \% 20$ tutorial\%20guide.pdf

Hetsroni, G., Mosyak, A., Pogrebnyak, E., \& Yarin, L. P. (2005). Fluid flow in micro-channels. International Journal of Heatnand Mass Transfer, $\quad 48(10), \quad$ 1982-1998. https://doi.org/https://doi.org/10.1016/j.ijheatma sstransfer.2004.12.019
Jajja, S. A., Ali, W., Ali, H. M., \& Ali, A. M. (2014). Water cooled minichannel heat sinks for microprocessor cooling: Effect of fin spacing. Applied Thermal Engineering, 64(1), 76-82. https://doi.org/https://doi.org/10.1016/j.applther maleng.2013.12.007

Kim, K.-S., Won, M.-H., Kim, J.-W., \& Back, B.-J. (2003). Heat pipe cooling technology for desktop PC CPU. Applied Thermal Engineering, 23(9), 1137-1144.

https://doi.org/https://doi.org/10.1016/S13594311(03)00044-9

Knight, R. W., Hall, D. J., Goodling, J. S., \& Jaeger, R. C. (1992). Heat sink optimization with application to microchannels. IEEE Transactions on Components, Hybrids, and Manufacturing Technology, 15(5), 832-842. https://doi.org/10.1109/33.180049

Naphon, P., Klangchart, S., \& Wongwises, S. (2009). Numerical investigation on the heat transfer and flow in the mini-fin heat sink for CPU. International Communications in Heat and Mass Transfer, 36(8), 834-840. https://doi.org/https://doi.org/10.1016/j.icheatm asstransfer.2009.06.010

Naphon, P., \& Wiriyasart, S. (2009). Liquid cooling in the mini-rectangular fin heat sink with and without thermoelectric for CPU. International Communications in Heat and Mass Transfer, 36(2), 166-171. https://doi.org/https://doi.org/10.1016/j.icheatm asstransfer.2008.10.002

Nishino, K., Samada, M., Kasuya, K., \& Torii, K. (1996). Turbulence Characteristics in the Stagnation Region of an Axisymmetric Impinging Jet Flow. Transactions of the Japan Society of Mechanical Engineers Series B, 62(594), 474-482. https://doi.org/10.1299/kikaib.62.474

Pastukhov, V. G., \& Maydanik, Y. F. (2006). Low-noise cooling system for pc on the base of loop heat pipes. Twenty-Second Annual IEEE Semiconductor Thermal Measurement And Management Symposium, 95-101. https://doi.org/10.1109/STHERM.2006.162521 2

Réti, F. (1999). Liquid cooling of electronic devices by single-phase convection (Wiley - Interscience Publication, 1999, New York - Chichester Weinheim - Brisbane - Singapore - Toronto) Frank P. Incropera. Journal of Thermal Analysis and Calorimetry, 58(3), 749. https://doi.org/10.1023/A:1010174209771

Tiselj, I., Hetsroni, G., Mavko, B., Mosyak, A., Pogrebnyak, E., \& Segal, Z. (2004). Effect of axial conduction on the heat transfer in micro- 
channels. International Journal of Heat and Mass Transfer, 47(12), 2551-2565. https://doi.org/https://doi.org/10.1016/j.ijheatma sstransfer.2004.01.008

Toh, K. C., Chen, X. Y., \& Chai, J. C. (2002). Numerical computation of fluid flow and heat transfer in microchannels. International Journal of Heat and Mass Transfer, 45(26), 5133-5141. https://doi.org/https://doi.org/10.1016/S00179310(02)00223-5

Tuckerman, D. B., \& Pease, R. F. W. (1981). Highperformance heat sinking for VLSI. IEEE Electron Device Letters, 2(5), 126-129. https://doi.org/10.1109/EDL.1981.25367

Wang, B. X., \& Peng, X. F. (1994). Experimental investigation on liquid forced-convection heat transfer through microchannels. International Journal of Heat and Mass Transfer, 37, 73-82. https://doi.org/https://doi.org/10.1016/00179310(94)90011-6

Wang, Y., \& Vafai, K. (2000). An experimental investigation of the thermal performance of an asymmetrical flat plate heat pipe. International
Journal of Heat and Mass Transfer, 43(15), 2657-2668.

https://doi.org/https://doi.org/10.1016/S00179310(99)00300-2

Wei, X., \& Joshi, Y. (2003). Optimization study of stacked micro-channel heat sinks for microelectronic cooling. IEEE Transactions on Components and Packaging Technologies, 26(1), 55-61. https://doi.org/10.1109/TCAPT.2003.811473

Xie, X. L., Tao, W. Q., \& He, Y. L. (2006). Numerical study of turbulent heat transfer and pressure drop characteristics in a water-cooled minichannel heat sink. Journal of Electronic Packaging, 129(3), 247-255. https://doi.org/10.1115/1.2753887

Zhao, Z., \& Avedisian, C. T. (1997). Enhancing forced air convection heat transfer from an array of parallel plate fins using a heat pipe. International Journal of Heat and Mass Transfer, 40(13), 3135-3147.

https://doi.org/https://doi.org/10.1016/S00179310(96)00348-1 